\title{
Two-stage banana leaves wastes utilization towards mushroom growth and biogas production
}

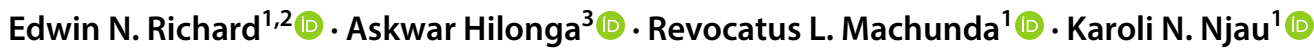

Received: 7 April 2020 / Accepted: 28 October 2020 / Published online: 20 November 2020

(c) King Abdulaziz City for Science and Technology 2020

\begin{abstract}
Banana leaves wastes (BL) were subjected to fungal treatment using Pleurotus ostreatus to produce edible mushrooms and biogas in the anaerobic digestion process. Effects of fungal treatment on mushrooms production, lignin degradation, trace elements compositions and biogas yield during the anaerobic digestion process were evaluated. Treatment with P.ostreatus for $36 \mathrm{~d}$ resulted in the production of $181 \pm 19 \mathrm{~g}$ of edible mushrooms per $2 \mathrm{~kg}$ of BL with biological efficiency of $37 \pm 4 \%$. Lignin concentration in fungal treated $\mathrm{BL}$ decreased by $10 \%$ indicating an improvement on its digestibility. Important trace elements ( $\mathrm{Fe}, \mathrm{Mn}, \mathrm{Mo}, \mathrm{Co}$ and $\mathrm{Ni}$ ) necessary for the improvement of the anaerobic digestion process were also significantly reduced $(P<0.05)$ during the fungal treatment process. The biogas yield for the fungal treated BL was $282 \mathrm{~mL} \mathrm{~g}^{-1} \mathrm{VS}^{-1}$ of which this study suggests that could be improved through trace element supplementation during the anaerobic digestion process.
\end{abstract}

Keywords Banana leaves $\cdot$ Mushrooms $\cdot$ Trace elements $\cdot$ Pleurotus ostreatus $\cdot$ Biogas

\section{Introduction}

Lignocelluloses materials contain an abundant source of sugars and, therefore, presents an excellent potential for the resources re-use and recovery; however, they comprise lignin, cellulose, and hemicellulose, which are highly recalcitrant and require pre-treatment to enhance their biodegradability (Akpinar and Urek 2017; Kucharska et al. 2018;

Edwin N. Richard

richarde@nm-aist.ac.tz

Askwar Hilonga

askwar.hilonga@nm-aist.ac.tz

Revocatus L. Machunda

revocatus.machunda@nm-aist.ac.tz

Karoli N. Njau

karoli.njau@nm-aist.ac.tz

1 Department of Water and Environmental Science and Engineering, Nelson Mandela African Institution of Science and Technology, 23311 Arusha, Tanzania

2 Department of Water Resources Engineering, University of Dar es Salaam, 16103 Dar es Salaam, Tanzania

3 Department of Materials Science and Engineering, Nelson Mandela African Institution of Science and Technology, 23311 Arusha, Tanzania
Thakur et al. 2013; Vasco-Correa and Shah 2019). In tropical countries such as Tanzania, several tons of unutilized banana by-products, including banana leaves, are generated daily (Padam et al.2014). Banana leaves wastes are mainly generated at the markets due to their application as wrapping materials for food, clothes, clay pots and cultural applications (Kennedy 2009). Since banana leaves are lignocellulosic, to utilize these wastes for energy recovery such as biogas production would require the pre-treatment to enhance their digestibility.

Different pre-treatment methods such as chemical, physical, physical-chemical and biological are used to enhance the digestibility of the lignocelluloses substrates (Monlau et al. 2013). Pre-treatment of lignocellulosic substrates with chemical, organosolv, ionic liquids or ozonolysis techniques require high operating costs, therefore, are not feasible at large scale applications (Ariunbaatar et al. 2014; Kumar and Sharma 2017). Additionally, handling by-products of chemicals pre-treatment substrates pose an environmental challenge due to formation of inhibitory compounds such as furans, phenolic compounds and carboxylic acids which can inhibit the growth of fermentative microorganisms (Baral and Shah 2014; Behera et al. 2014). Biological pre-treatment, on the other hand, is considered environmentally friendly and does not necessarily 
require chemicals and can be performed at mild conditions (Chaturvedi and Verma 2013; Rodriguez et al. 2017; Sari and Budiyono 2014). Some of the drawbacks of biological pre-treatments include microbes utilize part of carbohydrates during the pre-treatment process, and the process is prolonged (Cesaro and Belgiorno 2014; Mishra et al. 2018). Biological pre-treatment for enhancement of bioethanol and biogas production has mainly focused on pre-treatment by the specific microbial consortium, fungal pre-treatment, partial composting, enzymatic pretreatment and ensiling (Rouches et al. 2016; Wagner et al. 2018). Among all the available biological pre-treatments, fungal pre-treatment (FP) using a white-rot fungi species such as Pleurotus ostreatus (oyster mushroom), Ceriporiopsis Subvermispora, Trametes Versicolor, Coriolus Versicolor, Phanerochate Chrysoporium, and Cyathus Stercoreus have been considered as most capable of degrading the lignin of the most lignocellulosic substrates and of enhancing their digestibility for their subsequent applications (Abdel-Hamid et al. 2013; Rodríguez-Couto 2017; Thomsen et al. 2016).

Fungal species (e.g., Pleurotus ostreatus) have been used to pre-treat and to enhance hydrolysis process for biogas production of different substrates such as wheat straw, shore wood biomass, spent coffee grounds; and sugar bagasse to mention a few (Albornoz et al. 2018; Amirta et al. 2016; Wobiwo et al. 2018; Tuyen et al. 2013). Previous studies indicated that the lignocellulosic substrates such as wheat straw and shore wood could be pre-treated with $P$. ostreatus to improve their digestibility and hence to improve the anaerobic digestion process with a resultant increase of biogas and methane production (Albornoz et al. 2018; Amirta et al. 2016). However, to the best of our knowledge, there is no published report on the influence of fungal treatment on banana leaves wastes using P. ostreatus on trace elements, biomass composition and impacts on biogas production. Enhanced biogas production to the pre-treated samples is due to the fungal degradation of lignin which provides accessibility of cellulose for bacteria degradation in the AD process (Pérez-Chávez et al. 2019). However, different results by some studies (Wobiwo et al. 2018; Tuyen et al. 2013) showed that the pre-treatment with P. ostreatus on spent coffee grounds and sugarcane bagasse could lead to the loss of carbohydrates and hence the decrease in biogas in the anaerobic digestion process. Therefore, the recovery of the resources such as biogas (after fungal treatment) highly depends on the amount of organic matter left, type of fungal species used, pre-treatment duration, and the number of days for the anaerobic digestion process and the purpose of the pre-treatment. This study aimed to investigate the utilization of banana leaves towards mushroom production from $P$. ostreatus and biogas production. The influence of fungal treatment on banana leaves wastes using $P$. ostreatus on trace elements, biomass composition and biogas production was evaluated in this study.

\section{Materials and methods}

\section{Banana leaves wastes characterization}

The banana leaves wastes (BL) used in this study were collected in woven bags from National Milling Corporation (NMC) market, commonly known as Samunge in Arusha city, Tanzania $\left(3^{\circ} 22^{\prime} 36.0768^{\prime \prime} \mathrm{S}, 36^{\circ} 41^{\prime} 10.5396^{\prime \prime} \mathrm{E}\right)$. Banana leaves wastes comprises $23.6 \%$ of organic market wastes (Quantified under this study between May and September in the year 2019) as indicated in Fig. 1. Banana leaves are produced from several activities including ripening of bananas and as carrying materials for clay pots. The BL wastes were manually sorted out from the mixed waste streams at the market before the collection. The BL wastes were then brought to the Nelson Mandela African Institutions of Science and Technology (NM-AIST) laboratory where they were chopped into $5-10 \mathrm{~cm}$ in length using a bush knife and further air-dried for 7 days before characterization and the fungal treatment work. During characterization, a portion of BL was shredded into small pieces and then grounded with a mortar and a pestle. Total solids (TS), volatile solids (VS), fixed solids (FS) and moisture contents (MC) were measured gravimetrically following standard methods for the examination of water and wastewater samples (APHA 2012). To determine the carbon-nitrogen ratio $(\mathrm{C} / \mathrm{N})$, the organic wastes samples were dried in an oven (Binder-Ed 53) at $70^{\circ} \mathrm{C}$ for $24 \mathrm{~h}$, and the dried samples were crushed and grounded into powders using mortars and pestles before sieving them to obtain fine powders. About $3.3 \mathrm{mg}$ of each sample was analyzed for carbon, hydrogen, and nitrogen using a CHNSO analyzer (Flash 2000 organic elemental analyzer). For pH determination of organic wastes, $10 \mathrm{~g}$ of the dried wastes were mixed

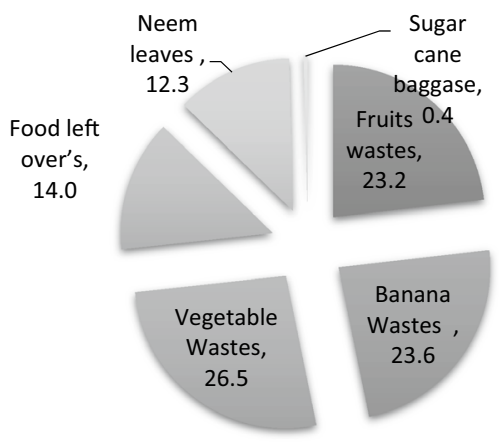

Fig. 1 Organic fraction market wastes compositions at Samunge market ( $\left.3^{\circ} 22^{\prime} 36.0768^{\prime \prime} \mathrm{S}, 36^{\circ} 41^{\prime} 10.5396^{\prime \prime} \mathrm{E}\right)$ 
with $100 \mathrm{ml}$ deionized water and centrifuged for $15 \mathrm{~min}$, then filtered through Whatman filter papers. The $\mathrm{pH}$ of the filtered solution was determined using a pH meter (HI 2209 $\mathrm{pH} / \mathrm{mV}$ Meter). Biomass compositions (lignin, cellulose and hemicelluloses) were determined according to the Chesson (Datta 1981; Maryana et al. 2014). The trace elements in BL were analyzed before and after the fungal treatment at Tanzania Atomic Energy Commission, Arusha, Tanzania, using Energy Dispersive X-ray Fluorescence technique (EDXRF) (Spectro Xepos, serial No. 4R0138, operated by $\mathrm{X}$-lab ProTM software). Some portion of the chopped and dried banana leaves were stored at $-20{ }^{\circ} \mathrm{C}$ to maintain their characteristics before anaerobic digestion process. Statistical analyses for the means differences in trace elements composition of the fungal treated and un-treated samples were conducted using $T$ test in Microsoft Excel 2010. Three replicates were used for each sample and results are expressed as mean and standard deviation.

\section{Fungal treatment of banana leaves wastes using Pleurotus ostreatus}

Fungal treatment of BL was carried out using the Spawn of the fungus, Pleurotus ostreatus $(\mathrm{PoH})$ which was procured from the Sokoine University of Agricultural in Tanzania. The spawns were stored at $4{ }^{\circ} \mathrm{C}$ at the NM-AIST laboratory before use. Fungal treatment was performed using locally available equipment and with the concept of industrial applications in developing countries perspectives. The treatment hut was locally constructed using the tree barks and covered at the top with the coconut leaves. Generally, the treatment involved pasteurization, spawning running (colonization) and formation of the fruiting bodies. Before pasteurization, the BL $(5-10 \mathrm{~cm})$ were soaked in water for two hours to soften it and was left to drain until no water was dripping from the substrates. The drained substrates were placed in layers into woven sacks sheets and pasteurized into $0.225 \mathrm{~m}^{3}$ metal drums with a platform of stones with sieves at the top to the height of $18 \mathrm{~cm}$ from the bottom. Firewood was used as the source of fuel, and for one batch of pasteurization for three hours, one bundle ( $15 \mathrm{~kg})$ of firewood was used. About 201 of water was poured inside the drum, the substrates were placed on the top of the platform, and the drum was covered with a metal lid. The pasteurization process took about $3 \mathrm{~h}$, and the temperatures inside the drum were measured using an infra-red thermometer (WT900, -50 to $950{ }^{\circ} \mathrm{C}$ ). The temperature inside the pasteurization drum varied from 92 to $124{ }^{\circ} \mathrm{C}$. The pasteurized substrates were allowed to cool and drain inside the drum for 1 day. Transparent polyethene sheets were used as packaging materials for the cooled pasteurized substrates. Before packaging, the sheets were cut into small pieces $(45 \mathrm{~cm}$ length), and the ends sealed using a candle flame. About $2 \mathrm{~kg}$ of the loosely pasteurized substrates (corresponding to $490 \mathrm{~g}$ dry weight) were weighed using a portable electronic spring balance and inoculated with $P$. ostreatus strain at the top and both sides inside the polyethene sheets. A total of 10 bags were used in this experiment. The already packed spawn substrates were incubated on wooden shelves which were disinfected with antibacterial sprays (Dettol) in the pre-treatment hut. To ensure enough darkness was available for spawn running, dark clothes were used to cover the spawned bags. In accordance to Tesfaw et al. (2015), light and relative humidity are pre-requisites for pinhead initiation after the completion of the spawn running. To ensure enough light and humidity the dark clothes covering the spawned bags were removed, and tiny holes were made into the bags using a syringe needle and clean water was sprayed once a day to the spawned bags. Temperature and humidity were measured using pocket weather meter (kestrel 3000) and were kept in the average temperature of $22{ }^{\circ} \mathrm{C}$ and $70-85 \%$ humidity. Biological efficiency which is the measure to assess the growth potential of mushrooms was determined as the percentage ratios of the fresh mushrooms harvested to the weight of the dry substrates (Vieira and de Andrade 2016).

\section{Anaerobic digestion process of fungal treated and un-treated banana leaves wastes}

Anaerobic digestion process for biogas production of the fungal treated and un-treated banana leaves was carried out in batch reactors. The batch reactor with cow dung only was treated as the control experiment. The other two batch reactors each contained $20 \mathrm{~g}$ of the fungal-treated and un-treated banana leaves which were ground and sieved to $2 \mathrm{~mm}$ sizes and added with $400 \mathrm{~mL}$ of cow dung adjusted to total solids (TS) of $6.1 \%$ with tap water. The cow dung was collected in a closed bucket from the Roman Catholic Church cattle hut beside the NM-AIST Campus in Arusha, Tanzania. All experiments were performed in duplicate in a $500 \mathrm{~mL}$ Erlenmeyer flask with an effective volume of $350 \mathrm{~mL}$. The batch reactors were sealed with rubber stoppers and were incubated in a water bath for 40 days at $37{ }^{\circ} \mathrm{C}$ and stirred manually three times a day for about $2 \mathrm{~min}$. The volume of the biogas produced was collected by displacement of water.

\section{Results and discussion}

\section{Characteristics of banana leave wastes used in the fungal treatment and anaerobic digestion process}

Table 1 depicts banana leaves characteristics before fungal pre-treatment. The TS and VS (\%TS) contents were 24.5 and $84.3 \%$, respectively, indicating that banana leaves are 
Table 1 Characteristics of banana leaves waste before fungal pretreatment (Mean \pm standard deviations of three replicates)

\begin{tabular}{lc}
\hline Component & Percentage (\%) \\
\hline Total solids (TS) & $24.5 \pm 0.4$ \\
Volatile solids (\%TS) & $84.3 \pm 0.5$ \\
Moisture contents (MC) & $75.5 \pm 0.4$ \\
$\mathrm{pH}$ & $8.2 \pm 0.1$ \\
Carbon to Nitrogen ratio (C/N) & $18.8 \pm 0.3$ \\
Cellulose & $28.9 \pm 0.9$ \\
Hemicelluloses & $23.5 \pm 1.1$ \\
Lignin & $18.9 \pm 0.5$ \\
\hline
\end{tabular}

suitable for fungal treatment. The $\mathrm{C} / \mathrm{N}$ and $\mathrm{pH}$ of the $\mathrm{BL}$ were within acceptable ranges for $\mathrm{FP}$ as reported by some authors. Bellettini et al. (2016) reported that the substrates with the $\mathrm{C} / \mathrm{N}$ ratio range between $15: 1$ and $25: 1$ and $\mathrm{pH}$ range between 6.5 and 7.0 are well suited for FP. The moisture content was adjusted to $75 \%$ as per Mustafa et al. (2016), who indicated that FP with P.ostreatus is most effective at $75 \%$ MC. The lignocellulosic components: cellulose, hemicellulose and lignin were also similar to the reported values for un-pretreated banana leaves as reported by some authors. Fernandes et al. (2013) reported the cellulose, hemicellulose and lignin for semi-dried banana leaves to be $26.7 \%, 25.8 \%$ and $17 \%$, respectively. In comparison with the biomass compositions of other substrates such as rice straw, beach wood, and palm midrib pre-treated with $P$. ostreatus, it seems hemicellulose and lignin contents which are mostly affected by P. ostreatus ranged from 11.2 to $22.9 \%$ and 13.1 to 22.9\%, respectively (Bari et al. 2015; Metri et al. 2018; Mustafa et al. 2016; Owaid et al. 2017). Therefore, the biomass compositions of the banana leave analyzed in this study fall within acceptable limits for the fungal treatment. The $\mathrm{pH}$ in anaerobic digestion process for untreated and treated BL were $7.90 \pm 0.02$, and $7.40 \pm 0.00$, respectively, and were within acceptable ranges for the AD process (Richard et al. 2019). According to Vögeli et al. (2014), substrates with more than $60 \%$ VS are suitable for resources recovery such as biogas production. In the current study, the VS for untreated and treated BL were 78.2 and $77.10 \%$, respectively, these were above $60 \%$ and, therefore, acceptable for biogas production.

\section{Fungal treatment of banana leaves wastes using Pleurotus ostreatus}

Table 2 indicates the number of days taken for spawn running, pinhead formation, the formation of fruiting bodies, number of clusters, yields and biological efficiency for ten mushroom bags used in the experiment. The spawn running took about 29 days; followed by an average of 3 days of pinhead formation. The complete fruit body formation and the mushroom harvest took about 36 days. The average weight of the mushroom harvested per $2 \mathrm{~kg}$ of BL bag was $181 \pm 19 \mathrm{~g}$ which was slightly lower than those reported by other authors (Amirta et al. 2016). The percentage of biological efficiency (BE) in this study was $37 \%$. The varying biological efficiency results with Pleurotus ostreatus, when cultivated in different substrates, have been reported in the literature. Yang et al. (2013) indicated that the BE with Pleurotus ostreatus when cultivated with sterilized rice and wheat straws supplemented with wheat bran (20\%) were found to be 53.9 and $51.3 \%$, respectively. Vieira and de Andrade ( 2016) studied the effect of the cultivation of oyster mushroom (P. ostreatus) on different potential materials namely; decumbens grass, brizantha grass, sugarcane bagasse and wheat straw with nitrogen supplementation. The results indicated that BE increased with nitrogen supplementation with $\mathrm{BE}$ ranging from $86.4 \%$ (wheat straw) to $123.9 \%$ (brizantha grass). In comparison to these findings, the BE value obtained in this study was low. However, the results obtained in this study was slightly higher than the results obtained by Girmay et al. (2016) who indicated the BE of $P$. ostreatus when cultivated in paper waste and wheat straw to be $34.2 \%$ and $35.9 \%$, respectively. Therefore, the difference in BE results with $P$. ostreatus is attributed to many factors including the spawn rate used, strain type, number of times the mushroom were harvested, and optimization conditions just to mention a few. Table 3 presents the results of the compositions of dry BL after fungal treatment. The VS of banana leaves after the fungal treatment was $75.7 \%$ which indicates the loss of about $10 \%$ VS from non- treated BL. The decreased VS means that part of the organic matter of the pretreated substrates was incorporated into fruiting body formation. The $\mathrm{pH}$ of the $\mathrm{BL}$ decreased approximately by two units after the fungal treatment. Rouches et al. (2016) indicated that the $\mathrm{pH}$ drop during fungal treatment is

Table 2 Mushroom formation, number of clusters, fruit bodies, yield, and biological efficiency

\begin{tabular}{lllllll}
\hline $\begin{array}{l}\text { Spawn running } \\
\text { (day) }\end{array}$ & $\begin{array}{l}\text { Pinhead formation } \\
\text { (day) }\end{array}$ & $\begin{array}{l}\text { Mushroom harvest } \\
\text { (day) }\end{array}$ & Clusters (Nos) & $\begin{array}{l}\text { Fruit bodies (Nos) } \\
\text { Yield (g of fresh } \\
\text { mushroom/2 kg of } \\
\text { the substrate) }\end{array}$ & $\begin{array}{l}\text { Biological efficiency } \\
(\%)\end{array}$ \\
\hline $29 \pm 3$ & $32 \pm 3$ & $36 \pm 3$ & $3 \pm 1$ & $32 \pm 8$ & $181 \pm 19$ & $37 \pm 4$ \\
\hline
\end{tabular}

Results comprise of the mean of ten mushroom bags \pm standard deviations 
Table 3 Composition of banana leaves after fungal treatment

\begin{tabular}{lcl}
\hline Component (\%) & Fungal treated & $\begin{array}{l}\% \text { decrease } \\
\text { after treat- } \\
\text { ment }\end{array}$ \\
\hline $\mathrm{pH}$ & $6.4 \pm 0.1$ & - \\
Volatile solids (\%TS) & $75.7 \pm 0.8$ & 10 \\
Cellulose & $26.9 \pm 0.7$ & 7 \\
Hemicelluloses & $17.9 \pm 0.7$ & 24 \\
Lignin & $16.9 \pm 0.6$ & 10 \\
\hline
\end{tabular}

probably caused by the release of acetyl groups during the delignification process. The biomass compositions, cellulose (CE), hemicelluloses (HCE) and lignin (LIG) decreased by $7 \%, 24 \%$ and $10 \%$, respectively, after the fungal treatment. This result suggests that hemicellulose and lignin were more degraded by $P$. ostreatus as compared to the cellulose and, therefore, in comparison to results reported in most studies which indicated cellulose was less degraded by P.ostreatus compared to lignin and hemicellulose (Bari et al. 2015; Metri et al. 2018; Owaid et al. 2017). The reduced lignocellulosic components mean that the insoluble fibres were hydrolyzed into soluble components which is beneficial for fermentative microorganisms activities during the recovery of biogas (Budzianowski 2016). In addition to the loss of the organic matter, Table 4 indicates that the trace elements (Fe, Mn, Co, Ni and Mo) in un-treated banana leaves was significantly higher than the treated banana leaves $(P<0.05)$ as tested by $\mathrm{T}$-test in regression analysis of $\mathrm{Ms}$ excel. The reduced trace elements in treated banana leaves indicate that mushrooms bio cumulates the trace elements from the cultivated substrates.

\section{Anaerobic digestion process of fungal treated and un-treated banana leaves wastes}

Figure $2 \mathrm{a}$ indicates the daily biogas yield for untreated and treated banana leaves. Both reactors showed the quick release of biogas after day 1 , and gradually decreased before

Table 4 Trace elements compositions in banana leaves before and after fungal treatment

\begin{tabular}{lrr}
\hline Trace elements & Before treatment & After treatment \\
\hline Fe $(\%)$ & $0.653 \pm 0.005$ & $0.399 \pm 0.004$ \\
Mn $(\%)$ & $0.054 \pm 0.007$ & $0.034 \pm 0.004$ \\
Mo $(\mathrm{ppm})$ & $20.833 \pm 6.714$ & $17.967 \pm 1.674$ \\
Co $(\mathrm{ppm})$ & $8.03 \pm 0.058$ & $6.50 \pm 0.000$ \\
Ni $(\mathrm{ppm})$ & $1.67 \pm 0.058$ & $1.60 \pm 0.000$ \\
\hline
\end{tabular}

Results comprise of the mean of three replicates \pm standard deviation (Mushroom bio cumulates the trace elements from the cultivated banana leaves)
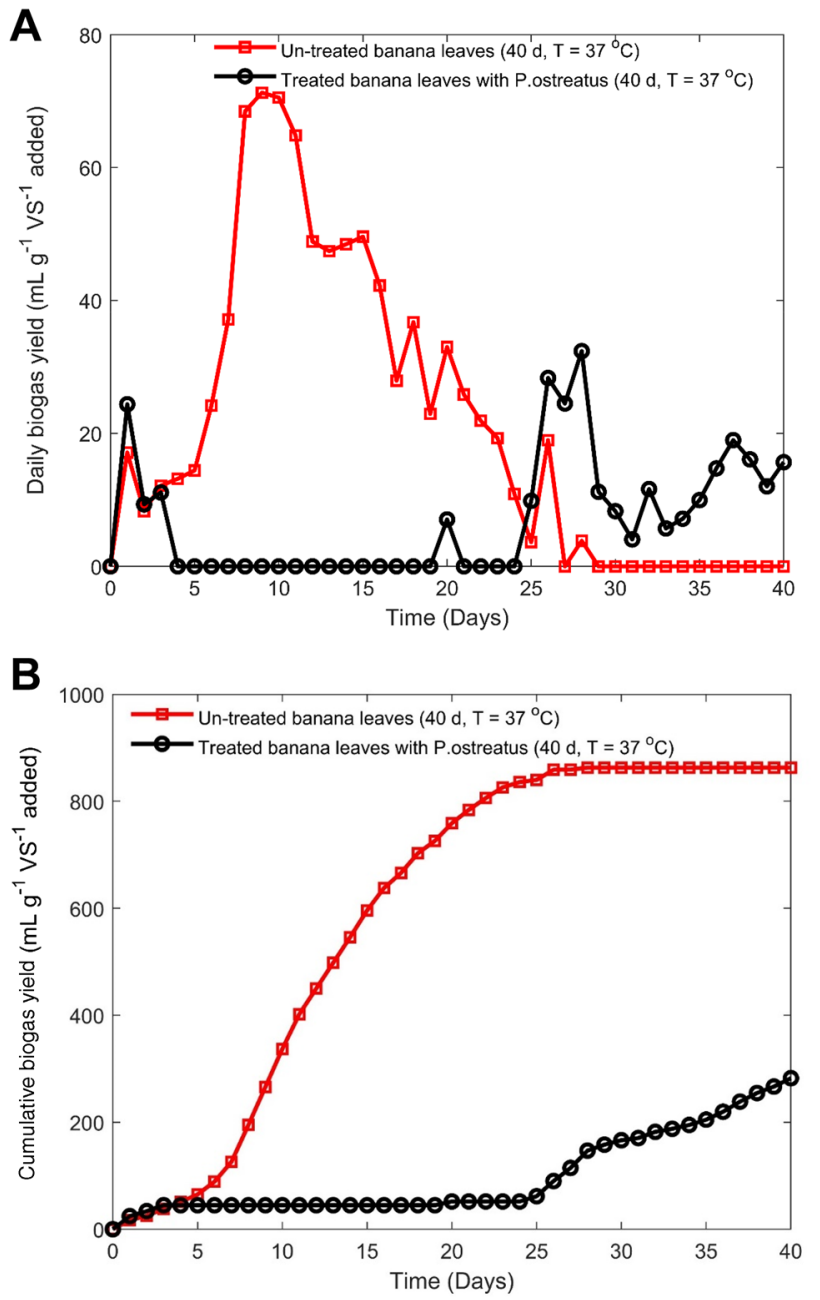

Fig. 2 a Daily biogas yields of un-treated and fungal treated banana leaves by P.ostreatus, data are means of the two replicates. b Cumulative biogas yields of un-treated and fungal treated banana leaves by $P$. ostreatus, data are means of the two replicates

it started to increase again. Within the first 2 days, the biogas yield in a fungal treated BL was slightly higher than that in un-treated BL but decreased to zero in day 4-19 before it started to increase again. The quick-release of biogas in a fungal treated BL may be attributed to reduced lignocelluloses components after fungal treatment with Pleurotus ostreatus. The peak daily biogas yield in fungal treated $\mathrm{BL}$ was $32.36 \mathrm{~mL} \mathrm{~g}^{-1} \mathrm{VS}^{-1} \mathrm{day}^{-1}$ which was observed in day 28 .

On the other hand, during the day 40 of the experiment the biogas yield in the un-treated BL was significantly higher $(P<0.05)$ as compared to the biogas yield in fungal treated $\mathrm{BL}$. The un-treated $\mathrm{BL}$ reactor showed a stable biogas production and a peak daily biogas yield of $71.26 \mathrm{~mL} \mathrm{~g}^{-1}$ $\mathrm{VS}^{-1} \mathrm{day}^{-1}$ which was observed in day 9 . Figure $2 \mathrm{~b}$ indicates the cumulative biogas yields for un-treated BL and fungal treated BL. After 40 days of the AD process, the cumulative biogas yield in the fungal treated $\mathrm{BL}$ was $282 \mathrm{~mL} \mathrm{~g}^{-1}$

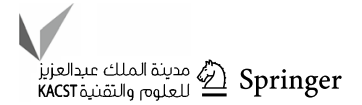


$\mathrm{VS}^{-1}$ which was 3 times lower than that of the un-treated BL $\left(863 \mathrm{~mL} \mathrm{~g}^{-1} \mathrm{VS}^{-1}\right)$. Nevertheless, the biogas yield trend results in Fig. 2 shows that the difference in the biogas yields between the un-treated and fungal treated BL could be reduced if the experiment would continue in more than 40 days (This experiment was terminated in day 40 , due to necessary stoppage of all lab activities and the closure of the university due to COVID 19 pandemic diseases outbreak).

The quick stable biogas yield in un-treated BL reactor during day 40 of the experiment may be attributed to the higher essential elements in un-treated banana leaves, as indicated in Table 4. In accordance to Banks et al. (2012), the addition of trace elements in the anaerobic digestion systems plays significant roles in improving enzyme activities, growth of methanogens and stability of the anaerobic digestion process. Therefore, according to this study, an improvement in biogas yield stability from fungal treated banana leaves with $P$. ostreatus would require among others the trace elements supplementation. The biogas production obtained by fungal treatment of banana leaves with $P$. ostreatus in a comparison with other pre-treatment techniques of banana leaves is discussed below. The findings from Chanakya and Sreesha (2012) indicated that retting as a pre-treatment of banana leaves in a plug flow digester at the retention time of $30 \mathrm{~d}$ resulted in a biogas yield of $400 \mathrm{~mL} \mathrm{~g}^{-1} \mathrm{TS}^{-1}$ at room temperature of $28^{\circ} \mathrm{C}$ after 40 days of digestion. This biogas yield was considerably higher than the biogas yield of $282 \mathrm{~mL} \mathrm{~g}^{-1} \mathrm{VS}^{-1}$ (corresponding to $214 \mathrm{~mL} \mathrm{~g}^{-1} \mathrm{TS}^{-1}$ ) observed in our study. In another study, Jena et al. (2020) investigated the influence of $\mathrm{FeCl}_{3}$ addition as the means to improve the biogas production from semi-dried banana leaves. The addition of $\mathrm{FeCl}_{3}$ resulted in the cumulative biogas production of $2105 \mathrm{~mL}$ (when the production by inoculum is subtracted) which was higher than the results obtained in the current study $(743 \mathrm{~mL})$. However, in another study by Kamdem et al. (2013), the biogas yield of $126 \mathrm{~mL} \mathrm{~g}^{-1} \mathrm{TS}^{-1}$ was obtained from physical treatment through size reduction of banana leaves which was lower in comparison with $214 \mathrm{~mL} \mathrm{~g}^{-1} \mathrm{TS}^{-1}$ obtained in this study. The reason for the lower biogas yield as indicated in their study was high lignin concentration in banana leaves which affected the digestibility. In our study, the fungal treatment enhanced lignin degradation by $10 \%$. Generally, this study shows that Pleurotus ostreatus can be cultivated on banana leaves wastes to produce Oyster mushrooms which result to the enhancement of the lignocellulose digestibility of the banana leaves wastes for the biogas recoveries, and this creates a sustainable means to manage un-utilized banana leaves wastes.

The $\mathrm{pH}$ after the AD process was 7.18 and 7.3 for fungal treated and untreated $\mathrm{BL}$, respectively, which was slightly alkaline and suitable for the methanogenic process (Zhao et al. 2019). After $40 \mathrm{~d}$ of the AD process, the volatile solid removal efficiencies were $4.1 \%$ and $5.6 \%$ for fungal treated and un-treated BL, respectively, and this suggests that the experiment would require more time for more organic matter removal in the process. The total alkalinity increased after the $\mathrm{AD}$ process from 2247 to $434 \mathrm{mg} \mathrm{CaCO}_{3} \mathrm{~L}^{-1}$ and from 2189 to $4974 \mathrm{mg} \mathrm{CaCO}_{3} \mathrm{~L}^{-1}$ for un-treated and fungal treated BL, respectively. The increase of the total alkalinity is mainly attributed to the breakdown of protein and amino acids which generate ammonia. The ammonia generated help to contribute to the formation of $\mathrm{NH}_{4}\left(\mathrm{HCO}_{3}\right)$ buffer when combines with $\mathrm{CO}_{2}$ and $\mathrm{H}_{2} \mathrm{O}$ as per Eq. 1 resulting to the process stability of the batch reactors (Shen et al. 2016). The volatile fatty acids accumulation decreased after 40 days of the AD process from 2415 to $613 \mathrm{mg} \mathrm{L}^{-1}$ and from 1440 to $633 \mathrm{mg} \mathrm{L}^{-1}$ for fungal treated and un-treated $\mathrm{BL}$, respectively. These VFAs concentrations were still significantly high and indicate that the total conversion of organic matter was not yet achieved. According to Maragkaki et al. (2018), the negligible or absence of VFAs in digestates of AD process indicates the total conversion of the organic matter to biogas. The VFA/Alkalinity ratio after the AD process were 0.12 and 0.13 for untreated and treated BL, respectively. The low VFA/Alkalinity ratios indicate that the methanogenic stage was stable and was not disturbed by VFAs in the AD process

$\mathrm{NH}_{3}+\mathrm{H}_{2} \mathrm{O}+\mathrm{CO}_{2} \rightarrow \mathrm{NH}_{4}\left(\mathrm{HCO}_{3}\right)$

\section{Conclusions}

Banana leaves wastes may be fungal treated using Pleurotus ostreatus to produce edible mushrooms and biogas. About $181 \pm 19 \mathrm{~g}$ of edible mushrooms per wet $2 \mathrm{~kg}$ of BL wastes and biogas yield of $282 \mathrm{~mL} \mathrm{~g}^{-1} \mathrm{VS}^{-1}$ from fungal treated BL were obtained in this study. It was also observed that as mushrooms grow the digestibility of the banana leaves is enhanced but mushroom growth caused the reduction of the important trace elements in the treated banana leaves $(\mathrm{Fe}$, $\mathrm{Mn}, \mathrm{Mo}$, Co and $\mathrm{Ni}$ ) necessary for the improvement of the anaerobic digestion process. Thus to improve biogas production from fungal treated banana leaves using P.ostreatus, it is very important to supplement trace elements in the anaerobic digestion process. Generally, this study shows that one of the sustainable means to manage un-utilized banana leaves wastes is through the production of edible mushrooms for food and biogas production for energy.

Acknowledgements This work was supported by the Nelson Mandela African Institution of Science and Technology (NM-AIST), the United Republic of Tanzania, through the African Development Bank (AFDB), Project No. P-Z1-IA0-016 and Grant No. 2100155032816. 
The authors are grateful for the support received from the sponsors, and Mr. Benjamin Minja for his support during experimental works.

Author contributions All authors read, helped in discussion and approved the final manuscript.

\section{Compliance with ethical standards}

Conflict of interest The authors declare that they have no conflict of interest in the publication.

\section{References}

Abdel-Hamid, AM., Solbiati JO, Cann, IKO (2013) Insights into lignin degradation and its potential industrial applications. In: Gadd G, Sariaslani S (eds) Advances in applied microbiology, 1st ed, vol. 82, pp. 1-28. https://doi.org/10.1016/B978-0-12-407679-2.00001 $-6$

Akpinar M, Urek RO (2017) Induction of fungal laccase production under solid state bioprocessing of new agroindustrial waste and its application on dye decolorization. 3 Biotech 7(2):1-10. https ://doi.org/10.1007/s13205-017-0742-5

Albornoz S, Wyman V, Palma C, Carvajal A (2018) Understanding of the contribution of the fungal treatment conditions in a wheat straw biorefinery that produces enzymes and biogas. Biochem Eng J. https://doi.org/10.1016/j.bej.2018.09.011

Amirta R, Herawati E, Suwinarti W, Watanabe T (2016) Two-steps utilization of shorea wood waste biomass for the production of oyster mushroom and biogas-a zero waste approach. Agric Agric Sci Procedia 9:202-208. https://doi.org/10.1016/j.aaspro.2016.02.127

APHA (2012) Standard methods for the examination of water and wastewater, 22nd edn. American Public Health Association, Washington, DC

Ariunbaatar J, Panico A, Esposito G, Pirozzi F, Lens PNL (2014) Pretreatment methods to enhance anaerobic digestion of organic solid waste. Appl Energy 123:143-156. https://doi.org/10.1016/j.apene rgy.2014.02.035

Banks CJ, Zhang Y, Jiang Y, Heaven S (2012) Trace element requirements for stable food waste digestion at elevated ammonia concentrations. Biores Technol 104:127-135. https://doi.org/10.1016/j. biortech.2011.10.068

Baral NR, Shah A (2014) Microbial inhibitors: formation and effects on acetone-butanol-ethanol fermentation of lignocellulosic biomass. Appl Microbiol Biotechnol 98:9151-9172. https://doi. org/10.1007/s00253-014-6106-8

Bari E, Nazarnezhad N, Kazemi SM, Ghanbary MAT, Mohebby B, Schmidt O, Clausen CA (2015) Comparison between degradation capabilities of the white rot fungi Pleurotus ostreatus and Trametes versicolor in beech wood. Int Biodeterior Biodegrad 104:231-237. https://doi.org/10.1016/j.ibiod.2015.03.033

Behera S, Arora R, Nandhagopal N, Kumar S (2014) Importance of chemical pretreatment for bioconversion of lignocellulosic biomass. Renew Sustain Energy Rev 36:91-106. https://doi. org/10.1016/j.rser.2014.04.047

Bellettini MB, Fiorda FA, Maieves HA, Teixeira GL, Ávila S, Hornung PS et al (2016) Factors affecting mushroom Pleurotus spp. Saudi J Biol Scie 26:633-646. https://doi.org/10.1016/j.sjbs.2016.12.005

Budzianowski WM (2016) A review of potential innovations for production, conditioning and utilization of biogas with multiplecriteria assessment. Renew Sustain Energy Rev 54:1148-1171. https://doi.org/10.1016/j.rser.2015.10.054
Cesaro A, Belgiorno V (2014) Pretreatment methods to improve anaerobic biodegradability of organic municipal solid waste fractions. Chem Eng J 240:24-37. https://doi.org/10.1016/j.cej.2013.11.055

Chanakya HN, Sreesha M (2012) Anaerobic retting of banana and arecanut wastes in a plug flow digester for recovery of fiber, biogas and compost. Energy Sustain Dev 16:231-235. https:// doi.org/10.1016/j.esd.2012.01.003

Chaturvedi V, Verma P (2013) An overview of key pretreatment processes employed for bioconversion of lignocellulosic biomass into biofuels and value added products. 3 Biotech 3:415-431. https:// doi.org/10.1007/s13205-013-0167-8

Datta R (1981) Acidogenic fermentation of lignocellulose-acid yield and conversion of components. Biotechnol Bioeng 23(9):21672170. https://doi.org/10.1002/bit.260230921

Fernandes ERK, Marangoni C, Souza O, Sellin N (2013) Thermochemical characterization of banana leaves as a potential energy source. Energy Convers Manag 75:603-608. https://doi.org/10.1016/j. enconman.2013.08.008

Girmay Z, Gorems W, Birhanu G, Zewdie S (2016) Growth and yield performance of Pleurotus ostreatus (Jacq. Fr.) Kumm (oyster mushroom) on different substrates. AMB Express 6:1-7. https:// doi.org/10.1186/s13568-016-0265-1

Jena SP, Mohanty UK, Mahapatra S (2020) Anaerobic digestion of semi-dried banana leaves in sewage water under the influence of certain additives. Mater Today Proc. https://doi.org/10.1016/j. matpr.2020.02.830

Kamdem I, Hiligsmann S, Vanderghem C, Bilik I, Paquot M, Thonart P (2013) Comparative biochemical analysis during the anaerobic digestion of lignocellulosic biomass from six morphological parts of Williams Cavendish banana (Triploid Musa AAA group) plants. World J Microbiol Biotechnol 29:2259-2270. https://doi. org/10.1007/s11274-013-1392-3

Kennedy J (2009) Bananas and people in the homeland of genus Musa: not just pretty fruit. Ethnobot Res Appl 7:179-198. https://doi. org/10.17348/era.7.0.179-197

Kucharska K, Rybarczyk P, Hołowacz I, Łukajtis R, Glinka M, Kamiński M (2018) Pretreatment of lignocellulosic materials as substrates for fermentation processes. Molecules 23:1-32. https ://doi.org/10.3390/molecules23112937

Kumar AK, Sharma S (2017) Recent updates on different methods of pretreatment of lignocellulosic feedstocks: a review. Bioresour Bioprocess. https://doi.org/10.1186/s40643-017-0137-9

Maragkaki AE, Fountoulakis M, Kyriakou A, Lasaridi K, Manios T (2018) Boosting biogas production from sewage sludge by adding small amount of agro-industrial by-products and food waste residues. Waste Manag 71:605-611. https://doi.org/10.1016/j. wasman.2017.04.024

Maryana R, Ma'rifatun D, Wheni AI, Satriyo KW, Rizal WA (2014) Alkaline pre-treatment on sugarcane bagasse for bioethanol production. Energy Proc 47:250-254. https://doi.org/10.1016/j.egypr o.2014.01.221

Metri Y, Warly L, Suyitman (2018) Biodegradation of lignin by white rot fungi (Pleurotus ostreatus) to decrease the fibre components in the palm midrib. Pak J Nutr 17:71-75. https://doi.org/10.3923/ pjn.2018.71.75

Mishra S, Singh PK, Dash S, Pattnaik R (2018) Microbial pretreatment of lignocellulosic biomass for enhanced biomethanation and waste management. 3 Biotech 8:458. https://doi.org/10.1007/ s13205-018-1480-z

Monlau F, Barakat A, Trably E, Dumas C, Steyer JP, Carrère H (2013) Lignocellulosic materials into biohydrogen and biomethane: Impact of structural features and pretreatment. Crit Rev Environ Sci Technol 43:260-322. https://doi.org/10.1080/10643 389.2011.604258

Mustafa AM, Poulsen TG, Sheng K (2016) Fungal pre-treatment of rice straw with Pleurotus ostreatus and Trichoderma reesei to

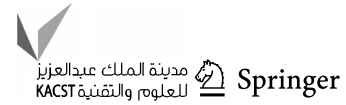


enhance methane production under solid-state anaerobic digestion. Appl Energy 180:661-671. https://doi.org/10.1016/j.apene rgy.2016.07.135

Owaid MN, Abed IA, Al-Saeedi SSS (2017) Applicable properties of the bio-fertilizer spent mushroom substrate in organic systems as a by-product from the cultivation of Pleurotus spp. Inform Process Agric 4:78-82. https://doi.org/10.1016/j.inpa.2017.01.001

Padam BS, Tin HS, Chye FY, Abdullah MI (2014) Banana by-products: an under-utilized renewable food biomass with great potential. J Food Sci Technol 51:3527-3545. https://doi.org/10.1007/s 1319 7-012-0861-2

Pérez-Chávez AM, Mayer L, Albertó E (2019) Mushroom cultivation and biogas production: a sustainable reuse of organic resources. Energy Sustain Dev 50:50-60. https://doi.org/10.1016/j. esd.2019.03.002

Richard EN, Hilonga A, Machunda RL, Njau KN (2019) A review on strategies to optimize metabolic stages of anaerobic digestion of municipal solid wastes towards enhanced resources recovery. Sustain Environ Res 29:1-13. https://doi.org/10.1186/s4283 4-019-0037-0

Rodríguez-Couto S (2017) Industrial and environmental applications of white-rot fungi. Mycosphere 8:456-466. https://doi.org/10.5943/ mycosphere/8/3/7

Rodriguez C, Alaswad A, Benyounis KY, Olabi AG (2017) Pretreatment techniques used in biogas production from grass. Renew Sustain Energy Rev 68:1193-1204. https://doi.org/10.1016/j. rser.2016.02.022

Rouches E, Herpoël-Gimbert I, Steyer JP, Carrere H (2016) Improvement of anaerobic degradation by white-rot fungi pre-treatment of lignocellulosic biomass: a review. Renew Sustain Energy Rev 59:179-198. https://doi.org/10.1016/j.rser.2015.12.317

Sari FP, Budiyono B (2014) Enhanced biogas production from rice straw with various pretreatment: a review. Waste Technology 2:1-25. https://doi.org/10.12777/wastech.2.1.17-25

Shen Y, Linville JL, Ignacio-de Leon PAA, Schoene RP, Urgun-Demirtas M (2016) Towards a sustainable paradigm of waste-to-energy process: Enhanced anaerobic digestion of sludge with woody biochar. J Clean Prod 135:1054-1064. https://doi.org/10.1016/j. jclepro.2016.06.144

Tesfaw A, Tadesse A, Kiros G (2015) Optimization of oyster (Pleurotus ostreatus) mushroom cultivation using locally available substrates and materials in Debre Berhan, Ethiopia. Journal of Applied Biology and Biotechnology 3:015-020. https://doi.org/10.7324/ jabb.2015.3103
Thakur S, Shrivastava B, Ingale S, Kuhad RC, Gupte A (2013) Degradation and selective ligninolysis of wheat straw and banana stem for an efficient bioethanol production using fungal and chemical pretreatment. 3 Biotech 3:365-372. https://doi.org/10.1007/s1320 5-012-0102-4

Thomsen ST, Londoño JEG, Ambye-Jensen M, Heiske S, Kádár Z, Meyer AS (2016) Combination of ensiling and fungal delignification as effective wheat straw pretreatment. Biotechnol Biofuels. https://doi.org/10.1186/s13068-016-0437-x

Tuyen DV, Phuong HN, Cone JW, Baars JJP, Sonnenberg ASM, Hendriks WH (2013) Effect of fungal treatments of fibrous agricultural by-products on chemical composition and in vitro rumen fermentation and methane production. Biores Technol 129:256-263. https://doi.org/10.1016/j.biortech.2012.10.128

Vasco-Correa J, Shah A (2019) Techno-economic bottlenecks of the fungal pretreatment of lignocellulosic biomass. Fermentation. https://doi.org/10.3390/fermentation5020030

Vieira FR, de Andrade MCN (2016) Optimization of substrate preparation for oyster mushroom (Pleurotus ostreatus) cultivation by studying different raw materials and substrate preparation conditions (composting: phases I and II). World J Microbiol Biotechnol. https://doi.org/10.1007/s11274-016-2152-y

Vögeli Y, Lohri CR, Gallardo A, Diener S, Zurbrügg C (2014) Anaerobic digestion of biowaste in developing countries: practical information and case studies. Swiss Federal Institute of Aquatic Science and Technology (Eawg), Dübendorf

Wagner AO, Lackner N, Mutschlechner M, Prem EM, Markt R, Illmer $\mathrm{P}$ (2018) Biological pretreatment strategies for second-generation lignocellulosic resources to enhance biogas production. Energies. https://doi.org/10.3390/en11071797

Wobiwo FA, Balbuena JLE, Nicolay T, Larondelle Y, Gerin PA (2018) Valorization of spent coffee ground with wheat or miscanthus straw: Yield improvement by the combined conversion to mushrooms and biomethane. Energy Sustain Dev 45:171-179. https:// doi.org/10.1016/j.esd.2018.06.012

Yang WJ, Guo FL, Wan ZJ (2013) Yield and size of oyster mushroom grown on rice/wheat straw basal substrate supplemented with cotton seed hull. Saudi J Biol Sci 20:333-338. https://doi. org/10.1016/j.sjbs.2013.02.006

Zhao T, Chen Y, Yu Q, Shi D, Chai H, Li L et al (2019) Enhancement of performance and stability of anaerobic co-digestion of waste activated sludge and kitchen waste by using bentonite. PLoS ONE 14:1-20. https://doi.org/10.1371/journal.pone.0218856 